\title{
Penerapan Ketentuan Praktik Sita Jaminan atas Saham Guna Memperoleh Kepastian Hukum
}

\section{The Legal Basis for Implementation of Shares Guarantee Seizure to Achieve Legal Certainty}

\author{
Adelia Audiana Gerchikova*, Anita Afriana \& Sherly Ayuna Putri \\ Program Studi Ilmu Hukum, Fakultas Hukum, Universitas Padjadjaran, Indonesia
}

Diterima: 11 April 2019; Disetujui: 5 Mei 2020; Dipublish: 2 Juni 2020

*Coresponding Email: agerchikova@yahoo.com, anita.afriana@gmail.com, sherly.ayunaputri@yahoo.com

\section{Abstrak}

Penelitian ini bertujuan untuk mengetahui ketentuan sita jaminan atas saham, dan mekanisme eksekusinya berdasarkan hukum positif yang berlaku guna memperoleh kepastian hukum dalam praktik pelaksanaan sita jaminan atas saham. Metode dalam penelitian ini adalah yuridis normatif, dengan spesifikasi penelitian deskriptif analitis. Analisis data dilakukan dengan menggunakan metode normatif kualitatif. Hasil penelitian menunjukan bahwa, pertama, ketentuan yang diberlakukan terhadap upaya sita jaminan atas saham adalah ketentuan dalam Pasal 227 ayat (1) HIR jo. Pasal 511 KUHPerdata, sehingga sita jaminan dapat dilaksanakan sepanjang memenuhi unsur pokok yang telah diatur dalam pasal tersebut. Kedua, terdapat perbedaan mekanisme eksekusi sita jaminan terhadap saham, dan kedua mekanisme tersebut tidak diatur dalam HIR sehingga menjadi tidak jelas, di sisi lain peraturan diciptakan untuk mencapai kepastian hukum. Dalam mencapai kepastian hukum diperlukan adanya produk hukum acara nasional dalam bentuk undang-undang (wet) yang dapat mengakomodir seluruh dinamika-dinamika hukum di Indonesia.

Kata Kunci: Sita Jaminan, Saham, Eksekusi, Kepastian Hukum.

\begin{abstract}
This research is intended to assert the legal basis for Shares Guarantee Seizure implementation, and execution mechanism towards Court Judgement of Permanent Legal Force, based on positive laws as an actual legal basis in order to achieve legal certainty as a practice of Shares Guarantee Seizure. The research is conducted through normative juridical method approach with descriptive analytical research specifications, and data analysis performed with qualitative methods. This study results shown, first, the actual legal basis for the efforts of Shares Guarantee Seizure is contained in article 227 section (1) of HIR in conjunction with Article 511 of The Indonesian Civil Code, as long as its implementation fulfills the basic requirements. Secondly, there are several distinct in the execution mechanisms of Shares Guarantee Seizure towards limited companies and both mechanisms have not been asserted in HIR, therefore the rule itself became unclear, whereas rules supposed to achieve legal certainty. To obtain legal certainty, new product regulations for Procedure of Civil Law are required in legislation (wet) arrangement, which should accommodate most of legal issues dynamics in Indonesia.
\end{abstract}

Kata Kunci: Guarantee Seizure, Stock, Execution, Legal Certainty

How to Cite: Gerchikova, A.A. Afriana, A. \& Putri, S.A (2020). Penerapan Ketentuan Praktik Sita Jaminan atas Saham Guna Memperoleh Kepastian Hukum, Jurnal Ilmiah Penegakan Hukum, 7 (1) 2020 : 8-16 


\section{PENDAHULUAN}

Hukum positif Indonesia telah mengatur perihal upaya hukum sita jaminan guna mencegah pengalihan harta kekayaan yang dimilikinya (Sutantio, 2009) dan bertujuan agar mampu menjamin gugatan Penggugat tidak hampa (illusioner) saat putusan telah berkekuatan hukum tetap, serta menjaga kepastian objek eksekusi, dengan cara melakukan penyitaan terhadap barang milik Tergugat, baik bergerak maupun tidak bergerak. Dapat diketahui bahwa sita jaminan merupakan suatu tindakan persiapan untuk menjamin dapat dilaksanakannya putusan perdata (Rorong, 2018).

Persoalan sita jaminan tidak terlepas dari permasalahan objek atau benda yang dimintakan, mengingat terdapat ketentuan-ketentuan yang membatasi untuk dilakukan sita atasnya, salah satunya ialah saham. Definisi saham sendiri ialah modal dasar Perseroan Terbatas yang memiliki nilai nominal tertentu (Sastrawidjaja, 2008). Saham tersebut sebagai suatu tanda masuk ikut serta dalam modal Perseroan yang pembagian modalnya dalam saham-saham tersebut dan diatur dalam Anggaran Dasar (Kansil, 2005), serta Anggaran Dasar tersebut merupakan bagian dari Akta Pendirian Perseroan Terbatas (Kurniawan, 2014).

Saham sendiri merupakan salah satu benda yang dikualifikasikan sebagai benda bergerak yang tidak berwujud, hal ini diatur dalam Pasal 511 KUHPerdata jo. Pasal 503 KUHPerdata (Meliala, 2015). Saham dapat dijadikan sebagai objek sita jaminan dengan syarat yang telah diatur dalam Pasal 227 ayat (1) HIR, dimana sita jaminan dapat dilakukan dengan dasar adanya sangkaan yang beralasan bahwa saham tersebut akan digelapkan atau dipindahtangankan oleh Tergugat. Kemudian, permasalahan muncul ketika terdapat pengaturan atau pedoman yang bertentangan dengan pelaksanaan sita jaminan terhadap saham, yaitu Buku II Pedoman Teknis Administrasi dan Teknis Peradilan Perdata Umum yang diberlakukan berdasarkan Keputusan Ketua Mahkamah Agung Nomor KMA/032/SK/IV/2006. Dalam huruf Y angka 11 pedoman tersebut mengatur bahwa Hakim tidak melakukan sita jaminan atas saham. Pertentangan ini memunculkan ketidakpastian hukum bagi Hakim saat menetapkan suatu sita jaminan dengan objek saham yang berdampak pada praktik pelaksanaannya yakni inkonsistensi hakim di pengadilan karena kesulitan dalam mengabulkan sita jaminan yang objeknya berupa saham, sehingga menimbulkan ambiguitas sistem peradilan nasional.

Apabila dilihat dari sudut pandang para hakim, sebagaimana diketahui hakim merupakan pengambil keputusan dalam sengketa yang ada, sehingga berkembang suatu pendapat yang dibuktikan dengan dikeluarkannya hasil Rakernas antara Mahkamah Agung RI dan para Ketua Pengadilan di seluruh lingkup peradilan yang secara tidak langsung membatasi gerak para hakim untuk dapat mengambil suatu keputusan berupa penyitaan dan pelaksanaan sita jaminan atas saham. Dalam Rakernas tersebut dijelaskan bahwa, suatu objek sita baru dapat disita apabila jelas mengenai barang apa yang hendak disita serta harus menyebutkan secara rinci identitas barang tersebut baik nama pemegangnya, jumlahnya dan tempat terdaftarnya (Balaga, 2004). Dalam artian, maka penetapan sita jaminan atas saham harus memerinci identitas pemilik saham, nomor seri, harga atau nilai yang tercantum dalam saham, kapan saham diperoleh, serta jumlah saham yang akan disita.

Mengingat kecenderungan yang berkembang di dunia peradilan bahwa pengadilan pada umumnya akan menolak permohonan sita jaminan atas saham apabila dalam permintaan sita tersebut tidak menyebut secara jelas identitasnya 
karena dianggap merupakan permintaan yang kabur objeknya, sehingga tidak mungkin diletakkan sita atasnya, sedangkan di sisi lain, diperkuat dengan adanya alasan mengapa hakim tidak diperbolehkan melakukan sita jaminan atas saham dalam Buku II Mahkamah Agung. Kemudian, permasalahan lain yang muncul dalam praktik pelaksanaan sita jaminan itu sendiri terletak pada mekanisme eksekusi sita jaminan terhadap saham apabila dikabulkan oleh hakim.

Beranjak dari permasalahan tersebut, adapun tujuan dilakukannya penulisan ini adalah untuk mengetahui ketentuan sita jaminan atas saham berdasarkan hukum positif yang seharusnya diberlakukan sebagai dasar hukum yang sebenarbenarnya guna memperoleh kepastian hukum dalam praktik pelaksanaan sita jaminan atas saham.

Terdapat keunggulan dalam karya ilmiah ini, yaitu Peneliti membahas dan menganalisis terlebih dahulu kedudukan hukum HIR dan Buku II Pedoman Teknis Administrasi dan Teknis Peradilan Perdata Umum dalam teori hierarki perundangundangan berdasarkan hukum positif yang seharusnya diberlakukan terhadap upaya sita jaminan atas saham, lalu diikuti dengan menganalisis kedudukan Rakernas, serta mengkaji mekanisme eksekusi sita jaminan saham dalam kerangka hukum acara perdata, sehingga praktik eksekusi tersebut dapat memperoleh kepastian hukum sesuai dengan cita-cita negara Indonesia sebagai negara hukum.

\section{METODE PENELITIAN}

Metode penelitian yang digunakan dalam penelitian ini adalah pendekatan yuridis normatif, yaitu berdasarkan pada studi kepustakaan, yang dilakukan dengan melihat literatur-literatur dan kaidah hukum dalam hukum positif yang berlaku terhadap masalah sita jaminan atas saham. Tahap penelitian ini dilakukan dengan mengedepankan data sekunder menggunakan bahan hukum primer berupa Undang-Undang Dasar 1945, Herzien Inlandsch Reglement, KUHPerdata dan peraturan perundang-undangan yang terkait lainnya. Terdapat bahan hukum sekunder meliputi buku-buku dan jurnal hukum, serta didukung dengan studi lapangan melalui hasil wawancara kepada sejumlah Hakim. Spesifikasi penelitian yang digunakan adalah deskriptif analitis dengan menggambarkan masalah dan fakta-fakta hukum secara menyeluruh untuk dianalisis secara yuridis kualitatif, yakni dengan bertitik tolak dari perundang-undangan yang berlaku dengan teori-teori hukum dan praktik pelaksanaan hukum positif terkait sita jaminan atas saham.

\section{HASIL DAN PEMBAHASAN}

Eksistensi Pengaturan Sita Jaminan atas Saham dalam HIR dan Buku II Pedoman Teknis Administrasi dan Teknis Peradilan Perdata Umum

Sita jaminan merupakan salah satu upaya untuk menjamin hak yang dilakukan dengan menyita benda-benda bergerak maupun tidak bergerak milik Tergugat, agar suatu putusan yang memenangkan pihak pemohon sita tidaklah illusoir (Mertokusumo, 2005). Ketentuanketentuan yang mengatur hukum acara perdata di Indonesia pada dasarnya tidak diatur dalam suatu wet atau undangundang dalam arti formil (Indrati, 2007), namun masih bergantung pada produk hukum hasil jajahan kolonialisme, yakni Herzien Inlandsch Reglement (HIR). Apabila dikaitkan dengan hierarki peraturan perundang-undangan dalam Pasal 7 ayat (1) UU No. 12 Tahun 2011 tentang Pembentukan Peraturan Perundang-undangan, HIR merupakan peraturan yang setara pada jenjang undang-undang.

Pengaturan terkait pembentukan hukum acara di Indonesia berdasarkan peraturan perundang-undangan, pertama kali dapat ditemukan pada ketentuan Pasal 24A ayat (5) UUD 1945. Pasal tersebut 
menjelaskan bahwa hukum acara Mahkamah Agung dan badan peradilan dibawahnya diatur oleh undang-undang. Dalam pasal tersebut, ditafsirkan sebagai undang-undang dalam arti formil (wet), yaitu undang-undang yang dibentuk oleh pembentuk undang-undang. Hal ini kemudian dapat dimengerti kaitannya dengan pembentukan UU No. 14 Tahun 1985 tentang Mahkamah Agung.

Dapat dipahami bahwa UU No. 14 Tahun 1985 tentang Mahkamah Agung sebagai perwujudan dari ketentuan Pasal 24A ayat (5) UUD 1945 memuat pengaturan-pengaturan terkait hukum acara. Hal ini mengingat Pasal 24A ayat (5) UUD 1945 mengatur bahwa hukum acara diatur dengan undang-undang, tidak terkecuali Hukum Acara Perdata.

Pembentuk undang-undang memberikan kewenangan bagi Mahkamah Agung untuk mengatur lebih lanjut hukum acara Mahkamah Agung, sebagaimana diatur pada Pasal 79 UU No. 14 Tahun 1985 tentang Mahkamah Agung, yang menjelaskan bahwa dalam satu kondisi Mahkamah Agung diberikan kewenangan untuk membentuk peraturan yang secara keseluruhan merupakan bagian dari hukum acaranya, ketika terjadi kekurangan atau kekosongan hukum.

Kekurangan atau kekosongan hukum menjadi indikator dari dilaksanakannya regelende functie Mahkamah Agung dalam membentuk hukum acara lanjutan guna melengkapi hukum yang telah ada, dan bukan membentuk suatu kaidah hukum untuk menggantikan kaidah hukum lain. Terutama produk hukum yang dibentuk tersebut sudah seharusnya tidak bertentangan dengan peraturan yang lebih tinggi karena berlaku asas "les superiori derogate legi inferiori".

Hal ini juga berlaku dalam hal pembentukan Buku II Pedoman Teknis Administrasi dan Teknis Peradilan Perdata yang merupakan interne regeling hasil kewenangan Mahkamah Agung dalam menjalankan fungsi pengaturan atau regelende functie. Dengan demikian, regelende functie Mahkamah Agung dalam pembentukan Buku II harus dimengerti ketika hukum acara yang diatur dalam buku pedoman tersebut, dibentuk untuk melengkapi kekurangan atau mengisi kekosongan hukum.

Dapat ditemukan pada bagian teknis peradilan, huruf Y (halaman 82) Buku II Pedoman Teknis Administrasi dan Teknis Peradilan Perdata. Akan tetapi, dalam pengaturan tersebut, terdapat ketentuan bahwa Hakim tidak melakukan sita jaminan atas saham. Ketentuan tersebut seharusnya dilihat sebagai pengaturan yang menggantikan pengaturan hukum acara yang sudah ada dan bukan merupakan regelende functie dari Pasal 79 UU No. 14 Tahun 1985 tentang Mahkamah Agung, mengingat tidak terjadinya kekosongan hukum ketika berbicara mengenai sita jaminan atas objek saham yang telah diatur dalam ketentuan Pasal 227 ayat (1) HIR jo. Pasal 511 KUHPerdata. Hal ini mengingat Pasal 227 ayat (1) HIR memungkinkan dilakukannya sita jaminan atas benda bergerak, yang mana saham sendiri dikualifikasikan sebagai benda bergerak tidak berwujud. Dengan demikian, jelas terlihat bahwa ketentuan terkait sita jaminan atas saham, bukanlah merupakan pengaturan yang kosong, atau belum diatur, melainkan telah diatur berdasarkan HIR.

Sita jaminan atas saham, sebagai suatu hukum acara yang telah diatur berdasarkan Pasal 227 ayat (1) HIR jo. Pasal 511 KUHPerdata, merupakan pengaturan yang diberlakukan sebagai hukum positif. Sementara itu, Buku II sebagai peraturan yang dibentuk berdasarkan atribusi kewenangan bagi Mahkamah Agung, sebagaimana ketentuan Pasal 79 UU No. 14 Tahun 1985 tentang Mahkamah Agung, tidaklah dapat menggantikan ketentuan pengaturan terkait sita jaminan atas saham yang telah diatur dalam HIR. Dengan demikian, secara kaidah hukum acara perdata, tidak benar 
apabila Hakim dalam putusannya menjadikan Buku II sebagai dasar hukum, mengingat Buku II bukanlah sebuah sumber hukum atau produk regulasi.

Berdasarkan hasil analisis terhadap eksistensi pengaturan mengenai sita jaminan terhadap saham, ketentuan yang diberlakukan terhadap praktik sita jaminan atas saham ialah ketentuan dalam HIR, sehingga sita jaminan atas saham dapat terlaksanakan atau dapat dimohonkan oleh pihak berperkara sepanjang memenuhi unsur pokok yang telah diatur dalam Pasal 227 HIR.

Unsur pokok yang harus diperhatikan sebagai dasar alasan untuk mengajukan sita jaminan berdasarkan Pasal 227 HIR, mengenai ketentuan yang harus diturut tentang dasar alasan apakah sita jaminan dapat dikabulkan, yaitu: 1) Ada sangka yang beralasan; 2) Tergugat mencari akal akan menggelapkan barang atau mencari akal akan mengasingkan barangnya kepada orang lain; 3) Dengan maksud akan menjauhkan barang itu dari haknya penggugat; 4) Dapat dikabulkan selama proses persidangan sedang berjalan (sebelum putusan dijatuhkan), atau sebelum putusan yang menghukumnya belum dapat dilaksanakan karena belum mempunyai kekuatan hukum tetap. Apabila salah satu unsur pokok tidak terpenuhi, maka Majelis Hakim wajib menolaknya.

Mekanisme Pelaksanaan Eksekusi Sita Jaminan atas Saham guna emperoleh Kepastian Hukum

Seperti yang telah dijelaskan sebelumnya, bahwa pengaturan mengenai sita jaminan telah diatur dalam HIR Pasal 227 ayat (1), dimana sita jaminan dapat dilaksanakan sepanjang syarat sita jaminan yakni "sangkaan yang beralasan bahwa Tergugat akan menggelapkan barang" dapat terbukti. Sehingga ketentuan huruf Y angka II dalam Buku II Pedoman Teknis Administrasi dan Teknis Peradilan Perdata Umum, yang menegaskan bahwa Hakim tidak melakukan sita jaminan atas saham, adalah tidak benar untuk dijadikan sebuah dasar hukum.

Dalam hasil wawancara yang dilakukan Peneliti dengan Hakim Mangapul Girsang, menjelaskan bahwa dalam praktik pengadilan, seorang Hakim tidak boleh menjadikan Buku II Pedoman Teknis Administrasi dan Teknis Peradilan Perdata Umum sebagai dasar pertimbangan, seharusnya menggali aturan induknya atau sumber hukum yang sebenarnya, mencari dasar hukum atau peraturan yang menjadi induk dari pada substansi dalam Buku II ini, seperti yang dipaparkan dalam Buku II itu adalah HIR, maka yang seharusnya menjadi dasar pertimbangan suatu putusan sita jaminan saham itu adalah HIR dan bukan Buku II, hanya karena semata-mata tidak ingin terkena sanksi hukum (kode etik) karena tidak mematuhi Buku II. Praktiknya, Buku II Pedoman Teknis Administrasi dan Teknis Peradilan Perdata Umum hanya bersifat buku bantu untuk para Hakim ketika tidak mengetahui suatu aspek hukum, dimana dalam pedoman tersebut mengangkat peraturan-peraturan sesungguhnya yang kemudian disusun menjadi Buku II Pedoman Teknis Administrasi dan Teknis Peradilan Perdata Umum (Mangapul Girsang, Hakim PN Jaksel).

Berbicara mengenai Rakernas, yang mengemukakan bahwa: "Dalam penetapan sita jaminan terhadap barang-barang bergerak harus memerinci identitas dan jumlah barang dalam arti disebut nama pemegangnya, jumlahnya dan tempat terdaftarnya.", Apabila diteliti lebih lanjut dengan melihat dari kedudukan hukumnya, Rakernas memiliki kedudukan yang berada di luar hukum positif yang berlaku di Indonesia, sehingga menjadi pertanyaan apakah Majelis Hakim sebagai pengambil keputusan dapat beracuan kepada Rakernas. 
Sebelumnya, perlu dicermati bahwa Rapat Kerja Nasional atau Rakernas menurut Bagir Manan, merupakan sebuah tradisi organisasi dimana dengan adanya Rakernas maka ada sebuah pikiran-pikiran baru, arahan-arahan baru, melakukan evaluasi capaian hasil-hasil yang lalu, menyampaikan pengalaman baru, temuan baru, masalah-masalah baru untuk dirembukkan bersama guna menemukan langkah-langkah selama satu tahun mendatang. Beliau juga menambahkan bahwa penyelenggaraan Rakernas sebagai upaya modernisasi pengadilan yang menjadi suatu keharusan dikarenakan kini peradilan Indonesia berhadapan dengan era modernisasi

(www.primaironline.com).

Senada dengan yang diungkapkan oleh Ketua Mahkamah Agung, Hatta Ali yang menyatakan tujuan Rakernas Mahkamah Agung adalah penyamaan persepsi tentang penerapan hukum. Dalam hasil wawancara yang dilakukan Peneliti dengan Hakim Agung, MD. Pasaribu, menjelaskan tujuan Rakernas juga untuk mendiskusikan dan memecahkan permasalahan teknis yuridis menuju pada pemahaman dalam rangka peningkatan profesionalisme Hakim dan kualitas putusan Hakim. Hal ini dikarenakan jajaran pengadilan di berbagai tingkatan, termasuk Mahkamah Agung kerap kali membuat putusan yang saling bertentangan dalam suatu jenis perkara yang memiliki kondisi sama, oleh karena itu harus disamakan persepsinya salah satunya dengan diadakannya Rakernas (Hakim Mahkamah Agung, MD. Pasaribu).

Dapat disimpulkan bahwa Rakernas diadakan untuk melakukan persamaan persepsi pada jajaran pengadilan di berbagai tingkatan, namun bukan berarti Majelis Hakim dapat memutuskan suatu perkara berdasarkan Rakernas, karena keputusan Hakim mengenai suatu perkara haruslah dengan alasan dan menggunakan dasar-dasar yuridis yang jelas seperti yang tercantum dalam Pasal 178 ayat (1) HIR.
Alasan-alasan hukum disini berisikan tentang sumber-sumber hukum sebagai dasar alasan yang mengabulkan atau menolak putusan tersebut. Dalam hal ini Rakernas bukan merupakan sumber hukum yang dapat digunakan bagi Hakim dalam memutus suatu perkara karena Rakernas hanyalah sebuah rapat internal dan bukan berupa suatu ilmu pengetahuan yang diakui banyak pihak atau berupa ajaran para ahli dan bukan pula suatu peraturan hukum.

Adapun Hukum Acara Perdata Positif yang dapat digunakan oleh Majelis Hakim salah satunya Putusan Mahkamah Agung RI sebagai yurisprudensi, sedangkan Rakernas hanya sebagai sebuah wadah untuk mendiskusikan dan memecahkan permasalahan yang terjadi dalam pengambilan putusan dimana yang didiskusikan adalah dasar hukum apa yang harus digunakan untuk menghadapi suatu perkara agar Hakim kedepannya dalam membuat putusan terhadap suatu jenis perkara yang memiliki kondisi sama sekali tidak saling bertentangan.

Hakim walaupun hanya secara lisan mengatakan perkara tersebut ditolak karena tidak sejalan dengan Rakernas, namun hal itu tetap tidak dapat dibenarkan untuk menjadikan Rakernas sebagai dasar alasan hukum untuk ditolaknya suatu perkara, karena seharusnya Hakim tidak mengatakan secara lisan tetapi akan lebih baik apabila Majelis Hakim menulis dalam putusannya disertai dengan dasar hukum apa yang mendasari ditolaknya permohonan sita jaminan atas saham tersebut, dikarenakan objek sita jaminan yang dimohonkan tidak disebutkan secara terperinci. Hal seperti ini tentunya hanya akan menimbulkan kesimpang-siuran terhadap proses peradilan.

Kembali pada ketentuan Buku II Pedoman Teknis Administrasi dan Teknis Peradilan Perdata Umum huruf Y angka 11 bahwa: "Hakim tidak melakukan sita jaminan atas saham" dan angka 12 bahwa: 
"Pemblokiran atas saham dilakukan oleh Bapepam atas permintaan Ketua Pengadilan Tinggi dalam hal ada hubungan dengan perkara.", Berdasarkan hasil analisis, ketentuan tersebut hanya diberlakukan bagi permohonan sita jaminan atas saham-saham milik Perseroan Terbuka (go public) yang berada pada Bursa Efek, dengan pemblokiran efek yang dilakukan oleh OJK dan bukanlah Hakim (Hasil wawancara Peneliti dengan Hakim PN Bandung, Mangapul Girsang), sehingga ketentuan tersebut tidak dapat diberlakukan bagi penyitaan saham konvensional atau saham pada Perseroan Tertutup.

Dalam praktiknya, mekanisme eksekusi sita jaminan terhadap saham pada Perseroan Tertutup, tidak terdapat problematika saat pelaksanaannya. Tidak adanya hambatan dalam mekanisme eksekusi sita jaminan saham Perseroan Tertutup dikarenakan penyitaannya bersifat administratif, dimana sifat saham itu tidak berwujud sehingga lebih memiliki makna yuridis (Hasil wawancara Peneliti dengan Hakim PN Jaksel, Djoko Indiarto). Saat proses eksekusi, cukup dengan juru sita menyatakan jumlah lembaran saham dan identitas kepemilikannya yang kemudian penetapan sita saham tersebut didaftarkan di Departemen Hukum dan Hak Asasi Manusia (Depkumham).

Pengalihan saham sendiri diawali dengan perubahan akta pendirian, yang didalamnya terdapat susunan pengurus, anggaran dasar, dan identitas kepemilikan saham, yang didaftarkan di Depkumham, oleh karena itu penyitaanpun dilakukan di Depkumham. Jadi, apabila terdapat transaksi jual-beli saham yang dituangkan dalam akta notaris dalam rangka mengalihkan kepemilikan saham, akta notaris baru tersebut yang juga merupakan perubahan anggaran dasar harus didaftarkan di Depkumham, sehingga langsung terdeteksi jika terdapat perubahan kepemilikan saham.
Berdasarkan pembahasan di atas, dapat diketahui bahwa hambatan dalam mekanisme eksekusi sita jaminan saham hanya terjadi pada penyitaan atas saham go public karena saham tersebut berada pada Bursa Efek. Apabila dikaitkan dengan problematika ketentuan sita jaminan saham dalam Buku II angka 11, pada hakikatnya, secara yuridis boleh disita tetapi dalam pelaksanaannya sudah diketahui akan sulit dilaksanakan, bagaimana mendaftarkan ke Depkumham karena tidak diketahuinya seri daripada saham tersebut, oleh karena itu penyitaan tersebut menjadi tidak efektif karena kesulitan mengidentifikasi saham yang berada di Bursa Efek.

Sulitnya mengidentifikasi saham yang berada di Bursa Efek, karena diperlukan adanya kerjasama dengan pihak Bursa Efek untuk mengetahui nomor seri kepemilikan, hal tersebut tidak mudah dan memakan waktu yang lama, karena diperlukan serangkaian izin dari beberapa instansi. Sedangkan, mengenai saham Perseroan Tertutup, hanya melihat pada akta pendirian atau perubahan akta pendiriannya, di dalamnya tercantum pemilik saham dan jumlah saham, berhubung saham tersebut tidak ada nomor serinya. Begitu dinyatakan jumlah saham yang akan disita, lalu dinyatakan sah dan berharga, maka pihak Pengadilan melalui juru sita langsung mendaftarkan ke Depkumham, agar yang bersangkutan tidak mengalihkan sahamnya, karena pengalihan saham sendiri harus melalui perubahan akta yang didaftarkan di Depkumham.

Jadi, ketentuan dalam Buku II bukan melarang secara mutlak tetapi teknisnya yang sulit dilakukan sehingga tidak memungkinkan untuk dilaksanakan sita atas saham. Harus dipahami pula mengenai syarat dalam Rakernas ini berlaku bagi penyitaan saham go public saja (Hasil wawancara Peneliti dengan Hakim PN Bandung, Mangapul Girsang). 
Ketika seorang Hakim mengabulkan atau tidak mengabulkannya suatu perkara sita jaminan saham, Hakim tersebut harus memiliki pemikiran bahwa penyitaan tersebut dapat dilaksanakan atau tidak, karena mengalami kesulitan untuk menyimpulkan, maka kecenderungannya menjadi tidak dikabulkan. Hal tersebut dikarenakan alasan yuridis dalam menetapkan penolakan sita, bahwa Pemohon sendiri tidak bisa menjelaskan identitas sahamnya. Dengan tidak diketahuinya identitas saham yang sistemnya dalam suatu bursa, maka tidak mungkin dapat terlaksana. Oleh karena tidak mungkin dapat dilaksanakan, maka tidak berdasar apabila Hakim mengabulkan permohonan sita jaminan atas saham, untuk apa dikabulkan, jika sudah diketahui bahwa eksekusi sita tidak dapat dilaksanakan (Hasil wawancara Peneliti dengan Hakim PN Bandung, Mangapul Girsang).

Negara Indonesia sebagai negara hukum memiliki konsekuensi untuk menjadikan hukum berfungsi sebagai pemberi kepastian hukum dan keadilan (Aridhayandi, 2018). Secara keseluruhan, peraturan diciptakan untuk mencapai kepastian hukum jika melihat kembali pada cita-cita hukum Indonesia. Belum terciptanya produk pengaturan Hukum Acara Perdata merupakan salah satu contoh ketidaksadaran para legislator dalam menciptakan suatu produk hukum agar sesuai dengan yang diharapkan. Terjadi dualisme hukum apabila berbicara mengenai pengaturan hukum acara perdata yang masih diatur dalam HIR dan $\mathrm{RBg}$, dimana dinamika hukum di rezim terciptanya HIR tidak sesuai dengan perkembangan kultur Indonesia. Keberadaan hukum acara perdata yang merupakan warisan pemerintah Belanda belum mampu menjawab perkembangan kebutuhan masyarakat yang sangat dinamis (Agustine, 2017).

Dalam mencapai suatu kepastian hukum, sudah waktunya menciptakan
Hukum Acara Perdata Nasional yang dapat mengakomodir dinamika-dinamika hukum dan seluruh permasalahan perdata di Indonesia, melihat juga bahwa pengaturan sita jaminan khususnya saham dalam HIR masih tidak jelas dan menimbulkan ambiguitas sistem peradilan nasional. Jika sudah tercipta dalam suatu produk perundang-undangan, maka akan tercipta kepastian hukum dalam praktik pelaksanaan sita jaminan atas saham dalam rangka penyelesaian sengketa hukum acara perdata.

\section{SIMPULAN}

Ketentuan yang diberlakukan terhadap upaya sita jaminan atas saham yakni ketentuan pada Pasal 227 ayat (1) HIR jo. Pasal 511 KUHPerdata, sehingga sita jaminan dapat dilaksanakan sepanjang memenuhi unsur pokok yang telah diatur dalam pasal 227 HIR. Berkaitan dengan mekanisme eksekusi sita jaminan terhadap saham yang tidak diatur dalam HIR menjadikan peraturan itu sendiri menjadi tidak jelas, dan di sisi lain, peraturan diciptakan untuk mencapai kepastian hukum jika melihat kembali pada cita-cita hukum Indonesia. Untuk mencapai kepastian hukum diperlukan adanya produk hukum acara perdata nasional dalam sebuah bentuk undang-undang (wet) yang dapat mengakomodir dinamika-dinamika hukum, mengingat bahwa terdapat dualisme hukum pada produk hukum acara perdata saat ini. Jika sudah tercipta dalam suatu produk perundang-undangan, maka akan tercipta kepastian hukum dalam praktik pelaksanaan sita jaminan atas saham dalam rangka penyelesaian sengketa hukum acara perdata.

\section{DAFTAR PUSTAKA}

Agustine, D. (2017). Pembaharuan Sistem Hukum Acara Perdata. RechtsVinding, 6 (1): 1-7.

Aridhayandi, R. (2018). Kajian tentang Penerapan Sanksi Pidana terhadap Pelaku yang melakukan Perbuatan Curang dalam Bisinis Dihubungkan dengan Pasal 379a KUHP. Dialogia Iuridica, 8 (2):80-92. 
Balaga, R.A. (2004). Sita Jaminan (Conservatoir Beslag) atas Saham dalam Scripless Trading di Bursa Efek Jakarta, Tesis. Sekolah Pascasarjana Universitas Gadjah Mada.

Herzien Inlandsch Reglement (HIR).

Indrati, M.F. (2007). Ilmu Perundang-Undangan: Jenis, Fungsi, dan Materi Muatan. Yogyakarta: Kanisius.

Kansil, C.S.T \& Kansil, C. (2005). Hukum Perusahaan Indonesia (Aspek Hukum dalam Ekonomi). Jakarta: PT. Pradnya Paramita.

Keputusan Ketua Mahkamah Agung Republik Indonesia Nomor KMA/032/SK/IV/2006 Tentang Buku II Pedoman Teknis Administrasi dan Teknis Peradilan Perdata Umum.

Kitab Undang-Undang Hukum Perdata.

Kurniawan. (2014). Tanggung Jawab Pemegang Saham Perseroan Terbatas Menurut Hukum Positif. Mimbar Hukum, 26 (1): 70-83.

Meliala, D. (2015). Perkembangan Hukum Perdata Tentang Benda dan Hukum Perikatan. Bandung: Nuansa Aulia.

Mertokusumo, S. (2005). Hukum Acara Perdata. Yogyakarta: Liberty.
Napitupulu, T. (2018). Pembatasan Kewenangan Hakim untuk tidak melakukan Sita Jaminan atas Saham. Bina Mulia Hukum, 2(2): 151166.

Online, P. (2010). Persamaan Persepsi Penerapan Hukum Rakernas. Diunduh di http://www.primaironline.com/berita/detai l.php?catid=Peradilan\&artid=rakernas-marekomendasikan-persamaan-persepsipenerapan-hukum, tanggal 3 Januari 2020.

Rorong, Y. (2018). Kajian Hukum Tentang Sita Jaminan Terhadap Barang Milik Tergugat dengan Memperhatikan SEMA NO. 2 Tahun 1962 Tertanggal 25 April 1962. Lex Privatum, 6 (1): 69-76.

Sastrawidjaja, M. \& Mantili, R. (2008). Perseroan Terbatas Menurut Tiga Undang-Undang. Bandung: Alumni.

Sutantio, R. \& Oeripkartawinata, I. (2009). Hukum Acara Perdata dalam Teori dan Praktek. Bandung: Mandar Maju.

Undang-Undang Nomor 12 Tahun 2011 Tentang Pembentukan Peraturan Perundangundangan.

Undang-Undang Nomor 14 Tahun 1985 Tentang Mahkamah Agung. 